Pakistan Journal of Humanities \& Social Sciences Research Volume No. 02, Issue No. 01(June, 2019)

\title{
A COMPARATIVE STUDY TO EVALUATE ASSESSMENT FACILITIES AT GOVERNMENT SPECIAL EDUCATION SCHOOLS
}

\author{
Abid Masood*Hifsa Batool** \& Saleha Ashraf
}

\begin{abstract}
The present study attempts to evaluate the availability of assessment facilities at government special education schools and to make a comparison of these available facilities among assessment professionals. Professionals (Speech Therapist, Psychologist, and Audiometerist) working at government special education schools of Faisalabad and Multan are the population of the study. The sample of the study is $N=81$ professionals $(n=39$ Speech Therapists, $n=36$ Psychologists, and $n=06$ Audiometrists) selected through Simple random sampling technique. Assessment system evaluation questionnaire (ASEQ) is developed as a tool of study and reliability of the questionnaire is 0.886. It is found out after statistical analysis that the psychologist and speech therapist working at government special education institutes are in a greater amount as compare to audiometrists who are very few and it is found out that there is the significant difference among professionals related to the availability of assessment facilities for special students in government special education institutions. It is also analyzed that problems faced by the professionals regarding the assessment of special students at government special education schools have no significant difference. It is concluded that there should be arrangements for the availability of assessment material related to all assessment professionals in the schools so that they can do the best assessment that can be helpful in rehabilitation of special students.
\end{abstract}

*Govt. Special Education Department, Punjab (abidmasood1986@gmail.com)

**Govt Special Education Department, Punjab (hifsa763@gmail.com) 
Keywords: Speech Therapists, Psychologist, Audiometerists, Assessment, special students.

\section{INTRODUCTION}

In almost all societies, it is observed that there are some children with various disabilities, some children have defective vision some have impairment in hearing, some are intellectually disabled and some others are physically handicapped. Some children are slow learners and some others have remarkable learning (Alhabshan et al., 2017). The children, living different mode of life from normal also are taken into consideration a beneficial member of society although government and societies have to face a lot of problems in their rehabilitation. Education is not merely the opposite yet also the basic necessity of every human being. It creates the circumstance of a degree among groups of population and helps an individual to understand himself and his environments in which he is lodging (Robeyns, 2006).

Numerous elements play a place in enhancing the learning of all children as well as exceptional children (Loe \& Feldman, 2007). Assessment plays an important role in learning of exceptional children. If the assessment of the exceptional child is not been taken well then no realistic and great successes may be predicted. The core principle step is an assessment for higher fulfillment in learning of exceptional children (Brinkerhoff, 2002).

The term "assessment" actually is a process or method for the allocation of student's grades. Assessment is the pathway to calculate the knowledge and understanding of the individuals towards social occasions or social, and the students do the action as the instructions is given to settle in the social events. In the evaluation and estimating theories or models the assessment techniques are basic elements for measuring the reactions, knowledge of the individuals in the light of gained scores calculation and educational activities (Ravela et al., 2008). Results are prepared on the basis of findings through the assessment of students, the decisions within the classroom and out of the classroom, it's also pointed out that who students follow the instructions and who don't follow the instruction in the educational institution (Bishop, Mane \& Bishop, 2000).

To assess a child is the value of student engrossment in their activities (Rust, 2002). According to the learners, the assessment consistently differentiates the definite educational competence among the students (Knight, 2002). The 
assessment explored that whose students have a high level of understanding, whose students have the medium level of knowledge and whose students have a lower level of understanding as compared to other students. If you want to make positive changes in the students regarding their achievement then you replace the methods of assessment (Jimaa, 2011). The assessment is elaborated that what kind of students are serious in their learning and what kind of students are not learning. In fact, the teachers know the requirements and motivational of students through the assessment process (Yorke, 2003).

An assessment system is a combination of plans, policies, observations, and tools for forming and applying instructions on student's achievements. Actual assessment systems are that deliver knowledge of appropriate value and measure to meet investor statistics and supervisory needs in the care of better- worth and student training (Ravela et al., 2008). policymakers, international societies, and other investors are progressively identifying the importance of assessment for observing and refining student learning, and the attendant needs to establish strong systems for student assessment (McKinsey \& Company, 2007). This acknowledgment is related to rising confirmation that the profits of learning ensue to humanity merely as soon as learning come about (Hanushek \& Woessmann, 2009).

Ravela et al., (2008) reported that assessment is needed, but it should not be in ample, circumstance should be for successful teaching. There are certain indications that the just presence and distribution of evidence has a specific outcome on definite actors. But assessment is just one of the numerous basic components of the education program; others contain teacher training, teacher functioning situations, school administration and organization, curricular design, textbooks, and instructive constituents, expense on assessment materials proportionate to the necessities of diverse populations, and strenuous acts by those liable for education to determinate any complications exposed.

Certain societies debate that assessments, mostly hugescales assessment movements, are excessively costly. In reality, the conflicting inclines to be accurate, with testing presented to be between the minimum expensive advances in education development, costing far fewer than accumulative teachers' pays or decreasing class size. Hoxby (2002) stated that the maximum expensive public-level, examination packages in 
Europe charge less than $0.25 \%$ of per-pupil disbursements (Wolff, 2007). In the instance of assessments that tie learning and policy, "assessment" is demarcated as a system with the help of which scientists, policy-makers, and supporters interrelate to describe related questions or problems, activate specialists and capability and deliver possibilities for policymakers to think through (Clark \& Dickson, 1999).

In Pakistan, assessments don't reveal basic competency, open learning achievement of the children. In its place, in Pakistan education structure emboldens that individual who replicates their learning in the best way during schoolings and discourages individuals who are impotent to ensure it. It appears such as the entire structure of education turns related to the examination system. These kinds of assessments and estimations are slender in quality (Khan, 2006).

The assessment of adolescent students is diverse commencing the assessment of adult students and middle adults in numerous means. The utmost alteration is in the mean that adolescent students acquire. Who build their understanding in pragmatic, cooperating, concrete, and practical methods (Bredekamp \& Rosegrant, 1995) they do this via conceptual philosophy and paper and pencil analysis alone. To acquire, adolescent students must trace and influence items, form and generate in numerous means, pay attention and perform their daily activities and routine roles, conversations and singing, and change and performance in numerous customs and surroundings. Therefore, the appearance of what adolescent students identify and can organize in circumstances other than customary paper and pencil analysis.

The major aim of the present study is to evaluate the available assessment facilities in Special Education Institution of Pakistan. In Pakistan, the rare surveys and researches accomplished on the assessment facilities for special children at special education schools. It is the dire need of time to investigate such type of facilities for the rehabilitation of special children in a better way and become them a respected citizen of Pakistan. In Pakistan, some institutions and associations are giving attention to the assessment of special students. The researcher wants to explore the available assessment facilities for special children in special education schools in Faisalabad and Multan.

\section{OBJECTIVES OF THE STUDY}

The objectives of the current research are: 
1. To make a comparison of the available assessment facilities among professionals working in government education institutions.

2. To compare the problems faced by professionals during the assessment of special students at government special education institutions.

\section{QUESTIONS OF THE STUDY}

The questions of the present study are the following:

1. Is there a significant difference in the availability of assessment facilities among professionals in government special education institutions?

2. Is there a significant difference among the professionals related to the problems faced during the assessment of special students at government special education institutions?

\section{METHODOLOGY}

It is a descriptive study in nature and the survey method is used to collect the data.

\section{Population and sample of the study}

The population of the study is the professionals (Speech Therapist, Psychologist, and Audiometerist) working in special education schools of Faisalabad and Multan Division of Punjab Province. The sample of the study is $\mathrm{N}=81$ professionals $(\mathrm{n}=39$ Speech Therapists, $n=36$ Psychologists, and $n=06$ Audiometrists) selected through Simple random sampling technique. Professionals belonged to different special education schools of Multan and Faisalabad Division of Punjab.

\section{Instrument of study}

Assessment system evaluation questionnaire (ASEQ) is developed as an instrument of study to collect the data. ASEQ is 44 items Likert type scale and reliability of the questionnaire is 0.886 .

\section{RESULTS}

Table No 1: Availability of professionals in government special education schools.

\begin{tabular}{ccc}
\hline Designation & Frequency & Percent \\
\hline Psychologist & 36 & $44.4 \%$ \\
Speech Therapist & 39 & $48.1 \%$ \\
Audiometerist & 6 & $7.4 \%$ \\
\hline Total & 81 & $100 \%$ \\
\hline
\end{tabular}


The above Table No 1 explored that the representation of psychologists in the present study were $44.4 \%$, whereas the involvement of speech therapists were $48.1 \%$ and the representation of audiometers in the current research was $7.4 \%$.

Table No 2: Comparison of available assessment facilities among professionals for special students in government special education institutions.

\begin{tabular}{cccccc}
\hline Groups & $\begin{array}{c}\text { Sum of } \\
\text { Squares }\end{array}$ & Df & $\begin{array}{c}\text { Mean } \\
\text { Square }\end{array}$ & F & Sig \\
\hline $\begin{array}{c}\text { Between } \\
\text { Groups }\end{array}$ & 1103.84 & 2 & 551.92 & 7.45 & .001 \\
$\begin{array}{c}\text { Within } \\
\text { Groups }\end{array}$ & 5776.47 & 78 & 74.05 & & \\
\hline
\end{tabular}

The above Table No 2 explored that significant difference found among professionals regarding the availability of assessment facilities for special students in government special education institutions. It can be accomplished that the availability of assessment facilities can affect the assessment process of special students.

Table No 3: Comparison of problems faced by the professionals during the assessment of special students in government special education institutions.

\begin{tabular}{cccccc}
\hline Groups & $\begin{array}{c}\text { Sum of } \\
\text { Squares }\end{array}$ & Df & $\begin{array}{c}\text { Mean } \\
\text { Square }\end{array}$ & $F$ & Sig \\
\hline $\begin{array}{c}\text { Between } \\
\text { Groups }\end{array}$ & 235.38 & 2 & 117.69 & 2.19 & .118 \\
$\begin{array}{c}\text { Within } \\
\text { Groups }\end{array}$ & 4186.61 & 78 & 53.67 & & \\
\hline
\end{tabular}

The above Table No 3 explored that no significant difference found among the professionals regarding problems faced by them during the assessment of special students at government special education schools. It is also found out that no professional face more problems during the assessment of special students as compared to other professionals working in government special education institutions. 
Table No 4: Comparison of opinions of different professionals regarding the cooperation of parents and teachers refer to the assessment of special students in government special education institutions.

\begin{tabular}{cccccc}
\hline Groups & $\begin{array}{c}\text { Sum of } \\
\text { Squares }\end{array}$ & df & $\begin{array}{c}\text { Mean } \\
\text { Square }\end{array}$ & $F$ & Sig \\
\hline $\begin{array}{c}\text { Between } \\
\text { Groups }\end{array}$ & 377.63 & 2 & 188.81 & 3.45 & .037 \\
$\begin{array}{c}\text { Within } \\
\text { Groups }\end{array}$ & 4264.39 & 78 & 54.67 & & \\
\hline
\end{tabular}

The above Table No 4 explored that there is a significant difference found among the professionals regarding the cooperation of parents and teachers refer to the assessment of special students in government special education schools. It is also found out that the cooperation of parents and teachers can affect the assessment process of special students in government special education institutions.

\section{Findings}

The present study found that psychologists, speech therapists, and audiometrists working at special education schools are not in equal numbers and there are many schools which have psychologists and speech therapist but there is lack of audiometrists. As there is a lack of availability of all assessment professionals so assessment of special children is not properly done and it becomes a big hurdle in proper placement of special children. It is also found out that there is a significant difference in the availability of assessment facilities among assessment professionals working at special education institutions of government.

It is also analyzed that there is no significant difference in problems faced by the professionals related to the assessment of special students and there is the significant difference found among the professionals regarding the cooperation of parents and teachers refer to the assessment of special students at government special education schools.

\section{Recommendations}

It is recommended that government should make best arrangements for assessment facilities for the special students at special education institutions so that professionals can work their best without any problem and workshops and seminars 
should be arranged at government and semi-government level for the counseling of parents having special needs related to the importance of assessment and their role in assessment.

\section{REFERENCES}

Absolum, M., Flockton, L., Hattie, J., Hipkins, R., \& Reid, I. (2009). Directions for assessment in New Zealand: Developing students' assessment capabilities. Unpublished paper prepared for the Ministry of Education.

Alhabshan, R. F., Huwaymil, M. S. B., Alsaqabi, O. A., Alzaid, A. N., \& Almasoud, A. I. (2017). Assessment of Knowledge toward Complications of Diabetic Septic Foot among Diabetics Patients in Saudi Arabia. The Egyptian Journal of Hospital Medicine, 69(6), 2557-2562.

Barber, M., \& Mourshed, M. (2007). How the world's best-performing schools systems come out on top. McKinsey \& Company.

Bishop, M., Mane, F., \& Bishop, J. H. (2000). Secondary Education in the United States: What Can Others Learn from Our Mistakes?. Inter-American Development Bank.

Black, P., Harrison, C., \& Lee, C. (2003). Assessment for learning: Putting it into practice. McGraw-Hill Education (UK).

Brinkerhoff, J. M. (2002). Assessing and improving partnership relationships and outcomes: a proposed framework. Evaluation and program planning, 25(3), 215-231.

Cash, D., \& Clark, W. C. (2001). From science to policy: Assessing the assessment process. John F. Kennedy School of Government Faculty Research Working Papers Series RWP01045.

Clark, W. C., \& Dickson, N. M. (1999). The global environmental assessment project: Learning from efforts to link science and policy in an interdependent world. Acclimations, 8, 6-7.

Earl, L. M., \& Katz, S. (Eds.). (2006). Leading schools in a data-rich world: Harnessing data for school improvement. Corwin Press.

Gitay, H., Blanco, H., \& Biggs, R. (2005). Assessment Process. Ecosystems and Human Well-being, 119.

Hanushek, E. A., \& Woessmann, L. (2009). Schooling, cognitive skills, and the Latin American growth puzzle (No. w15066). National Bureau of Economic Research.

Hoxby, C. M. (2002). The cost of accountability (No. w8855). National Bureau of Economic Research.

Jimaa, S. (2011). The impact of assessment on students learning. Procedia-Social and Behavioral Sciences, 28, 718721.

Khan, S. (2006). An evaluation of the exercises provided in the English compulsory textbook for class X. Unpublished MA 
dissertation] Faculty of English Linguistics, University of Karachi.

Khattak, S. G. (2012). Assessment in schools in Pakistan. SAeDUC, 9(2).

Klinger, D. (2008). The evolving culture of large-scale assessments in Canadian education. Canadian Journal of Educational Administration and Policy, (76).

Knight, P. T. (2002). Summative assessment in higher education: practices in disarray. Studies in higher Education, 27(3), 275286.

Loe, I. M., \& Feldman, H. M. (2007). Academic and educational outcomes of children with ADHD. Journal of pediatric psychology, 32(6), 643-654.

McCulloch, M., \& House, S. (2007). An introduction to Assessment. Learning and Teaching Centre, University of Glasgow, 1-36.

Nagy, P. (2000). The three roles of assessment: Gatekeeping, accountability, and instructional diagnosis. Canadian Journal of Education/Revue canadienne de l'éducation, 262-279.

Noonan, B., \& Renihan, P. (2006). Demystifying assessment leadership. Canadian Journal of Educational Administration and Policy, 56, 1-21.

Ravela, P., Arregui, P., Valverde, G., Wolfe, R., Ferrer, G., Rizo, F., ... \& Wolff, L. (2008). The Educational Assessments that Latin America Needs.

Rehmani, A. (2003). Impact of public examination system on teaching and learning in Pakistan. International Biannual Newsletter ANTRIEP, 8(2), 3-7.

Rizvi, F. (2000). International education and the production of global imagination. na.

Robeyns, I. (2006). Three models of education: Rights, capabilities and human capital. School Field, 4(1), 69-84.

Rust, C. (2002). The impact of assessment on student learning: how can the research literature practically help to inform the development of departmental assessment strategies and learnercentred assessment practices?. Active learning in higher education, 3(2), 145-158.

United Nations. Department of Public Information. (2009). The millennium development goals report 2009. United Nations Publications.

Wolff, L. (2007). The costs of student assessmets in Latin America (No. 38). PREAL. 
Wooding, S., \& Grant, J. (2003). Assessing Research: The Researchers' View, Volume 2. Rand Europe Leiden (Netherlands).

Yorke, M. (2003). Formative assessment in higher education: Moves towards theory and the enhancement of pedagogic practice. Higher education, 45(4), 477-501. 